TURIZAM

Volume 24, Issue 4

178-193 (2020)

ORIGINAL

SCIENTIFIC PAPER

\section{Using Indicators to Assess Sustainable Tourism Development - The Case of Protected Natural Areas of Vojvodina (Northern Serbia)}

Igor TrišićA

Received: April 2020 | Accepted: August 2020

DOI: 10.5937/turizam24-26080

\begin{abstract}
The selected protected areas represent significant examples for analyzing the tourism offer whose results largely interpret the state and the perspective of sustainable development. Considering these indicators at the level of tourism development in the analyzed protected areas can contribute to the development of planning models and strategies of sustainable development. On the other hand, with proper implementation, the values of all elements of the environment that is significant for the users of the areas are directly improved which directly enables the sustainable development of a destination. Research data have been collected through a questionnaire, processed and displayed by the Chi-Square and Friedman Tests, which identified average values and obvious differences in displayed values of sustainable tourism development indicators in selected protected areas.
\end{abstract}

Keywords: Indicators of Sustainable Tourism, Tourism Development, Protected Areas, Ecotourism.

\title{
Introduction
}

The paper begins with the main hypothesis that certain indicators of sustainable development, at the level of protected natural areas, can completely condition the management of a tourism destination on the one hand, while on the other they directly affect the quality, complete living world (Gambino, 2015; Bennett et al., 2018) and geological forms of these areas (Carr et al., 2016). All the subjects in use affect the environment, and it is necessary to include tourists as significant users (Ballantyne, Packer, 2013). It is assumed that there is a significant difference in terms of the effects of different indicators of sustainable tourism development to a destination (Oprea et al., 2015). Those indicators are possibilities for the development of different forms of tourism, contributions to better ecological, social-cultural, and economic sustainability of the destination (Richins, 2009), which is one of the basic postulates of sustainable tourism development (Stojanović, Savić, 2013; Trišić, et al., 2020a; Hoang et al., 2020). Research data have

A University of Kragujevac, Faculty of Hotel Management and Tourism, Vrnjačka Banja; e-mail: trisici@hotmail.com 
been collected through a questionnaire, processed and displayed by the Chi-Square and Friedman Tests, which identified average values and obvious differences in displayed values of sustainable tourism development indicators in selected protected areas.

The topic of the research in this paper is the interdependence of tourism as a social phenomenon and the environment, about sustainable tourism development and its level of implementation in 7 selected protected natural areas of Vojvodina. At the same time, the development of tourism was conditioned by the quality of areas and environmental surroundings (Whitelaw et al., 2014; Kruger et al., 2017; Trišić, 2019).

The subject of the research in this paper is the certain indicators of sustainable tourism development in 7 protected natural areas in Vojvodina, within which tourist fluctuations are carried out. Whether the indicators of sustainable tourism development can influence the management of a tourism destination and its sustainable use is the goal of this paper. Incidentally, the selected natural areas can represent a significant sample for the analysis of values regarding significant tourism development of the region as a global tourism destination (Webb et al. 2018). The goal is linking protected areas to their region in efforts to combine nature protection and sustainable tourism and recreation (Brandt et al., 2013; Ward et al., 2018).

\section{Literature review}

Protected natural areas are important tourism destinations (Hall, 2010; Trišić et al., 202ob). Tourists around the world are increasingly opting for areas where they can realize various forms of nature-based tourism (Cvijanović et al., 2020). According to Kruger et al., (2017) protected natural areas attract tourists with natural and social factors. Tourism forms that can be realized in these destinations are mostly nature-based forms of tourism, events, wine-tourism, ecotourism and others (Holden, 2016). All forms of tourism impact the natural resources of these sensitive destinations (Minin et al., 2017). One of the most used resources within protected natural areas is water (Kostić et al., 2019). Through tourist activities, water can be used and polluted uncontrollably (Stojanović et al., 2018). The land is another important resource in protected natural areas (Maksin et al., 2018). It is used for the construction of tourism facilities. Uncontrolled construction of infrastructure and traffic within nature reserves can be a significant environmental problem (Eagles, 2014). The exploitation of natural resources, plants and animals is a serious problem in protected areas around the world (Lazić et al., 2008; Buclet, Lazarević, 2015).

To avoid these problems, it is necessary to protect natural areas. This protection includes the state, the local community and tourists in the systems of protection and management of these tourism destinations (Trišić, 2019). Protection is implemented at the international and local levels (Stojanović, Savić, 2013). This refers to the adoption of various laws and measures that protect protected natural areas. Without members of the local community, a sustainable tourism destination cannot be created. A quality tourism destination is one in which the local community accepts tourists and supports the development of tourism (Ward et al., 2018). Such a tourism destination has a positive effect on tourist satisfaction (Hodder et al., 2014; McCool, 2016). Ecological and socio-cultural results in such tourism destinations impact the creation of economic results (Fennell, Weaver, 2005). Significant financial results can be achieved through mass visits to protected natural areas (Valdivieso et al., 2015). Revenues from the tourist consumption within nature reserves can be financed in protection systems of natural areas (Leković, 2020). Such a circular system represents sustainable tourism development. 
Stojanović (2005) points out that the protected natural areas of AP Vojvodina have significant natural factors for the development of tourism. Such factors are landscapes, flora and fauna, rare geological forms, favorable climate, relief, favorable geographical location, diverse hydrography, vineyards and others (Lazić et al., 2008). There are also significant social factors such as settlements, monuments, events, wine routes, the folklore of the population (Pivac et al., 2020), which can be significant complementary tourism factors in Vojvodina.

Forms of tourism that can be developed within the protected natural areas of Vojvodina are ecotourism, scientific tourism, nature-based tourism, bird and animal watching, sports tourism, trips, fishing, hunting, hiking, nautical tourism, events, wine-tourism, etc. (Krstić et al., 2020).

Determining the existence of various factors within a tourism destination can be done by examining various subjective indicators of sustainable tourism development (Maksin et al., 2011). Indicators as factors can refer to certain segments within tourism planning. According to Maksin (2011) by measuring the indicators, certain impacts of tourists the area can be reduced. Indicators can indicate which factors or elements of the destination need to be strengthened to create a better quality tourism destination. In such a tourism destination, ecological, socio-cultural and economic conditions would be met, which is the basic task of sustainable tourism development (West et al., 2009).

\section{Methods and data}

\section{Study Area}

The area of the Autonomous Province of Vojvodina has 135 protected natural sites in the area of approximately $141,044.65$ ha. That is $6.56 \%$ of the total area of the territory of Vojvodina (Trišić et al., 2020a). This area covers significant protected areas, many of which possess the international conservation status. The protection of nature covers 1 national park, 2 landscapes of exceptional characteristics, 16 special nature reserves, 9 nature parks, 8 strict nature reserves, 23 natural monuments, 2 protected habitats, as well as natural assets of other categories (Lazić et al., 2008; Environmental protection programme of AP Vojvodina, for period 2016-2025 "Official Gazette of AP Vojvodina", 10/2016; Trišić et al., 2020a).

Among the protected areas, there are seven areas selected for the analysis of relevant indicators of sustainable tourism development in managing the tourism destination (established on natural elements). Those destinations are Special Nature Reserve "Deliblatska Peščara", National Park "Palić", and Special Nature Reserve "Meadows of Great Bustard" (Figure 1). These protected areas can share dual mandates of providing access to recreational areas for the public and of protecting biological diversity and resources for future generations (Muñoz et al., 2019).

\section{Methods}

To determine the condition of sustainable tourism development in each of the areas, it is necessary to conduct a proper analysis and valorization of basic elements and all potential indicators of sustainable tourism development (Fennell, 2015a; Liburd, Becken, 2017). It is also important to analyze the opinions of the users of these areas, from the viewpoint of the experiences and potential suggestions towards specific interventions to improve the condition of 


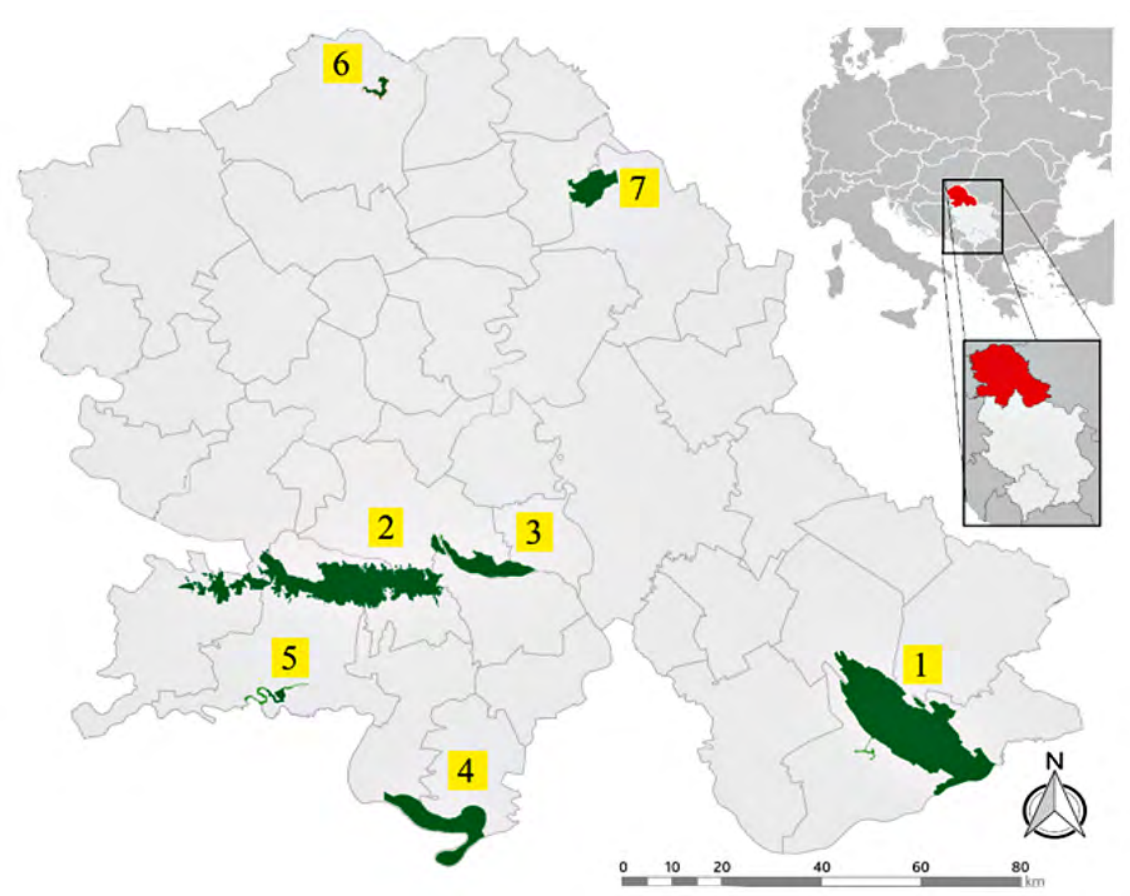

Figure 1. Map of Study Area

Legend: Special Nature Reserve "Deliblatska Peščara" (1); National Park "Fruška Gora" (2); Special Nature Reserve "Koviljsko-Petrovaradinski Rit" (3); Special Nature Reserve "Obedska Bara" (4); Special Nature Reserve "Zasavica" (5); Nature Park "Palić" (6); Special Nature Reserve "Meadows of Great Bustard" (7).

Source: Author digitalized

natural elements, statuses, and results of the area protection, which can increase benefits for all entities and users of these areas (Holden, 2016; Stojanović et al., 2018). System measures, the goals of protection, and expected results can be established when all roles of each indicator of sustainable tourism development have been defined and determined (Stojanović, 2005; Pfueller et al., 2011; Fennell, 2015b). From the above, it is important to conduct research and determine the significance of specific indicators within protected areas that affect sustainable tourism development of a destination and the level of area protection.

To determine the significance of specific indicators for sustainable tourism development in selected protected areas, the authors conducted a questionnaire between 450 users of these areas (n), during the visits, or after the completed travel. Written and online questionnaires were used in the research. For the online questionnaire, social networks and the method of a random selection of respondents were used, by sending the questionnaire to an e-mail address. A written questionnaire was used when visiting protected natural areas (Trišić et al., 2020a). The examination was performed during the fall of 2018 and the spring of 2019. As a part of the written questionnaire, they were asked 33 questions $=\left\{\mathrm{N}_{1}, \mathrm{~N}_{2} \ldots \mathrm{N}_{33}\right\}$, (Table 2) regarding the opinions toward certain indicators of sustainability within the visited area. Out of the total number of questions, 6 were related to possible negative indicators that can pose a threat to sustainable tourism development within a protected area $\left(\mathrm{N}_{2} 8 \ldots \mathrm{N}_{33}\right)$. Independent and dependent variables were examined in the study. Independent variables are indicators (33 indicators) that represent certain influences on the factors of sustainable tourism development in 
protected natural areas of Vojvodina (Table 2). Dependent variables are ecological, socio-cultural and economic sustainability within protected natural areas. Dependent variables are influenced by various factors and tourist activities (Maksin et al., 2011).

Under the elements for the research and a comparative analysis of sustainable development and protection, the integral parts of the destination were taken into account, as well as the endangered representatives of flora and fauna, the reasons and requirements of protection, the level of development and vulnerability, the anthropogenic effects classified according to the levels of application, the protection improvement methods, if it is stable, the role of the local community, and the sustainable results of proper management.

Respondents answered the question regarding tourism activities, and answers were ranked by a Likert scale (Joshi et al., 2015): a very low level of accuracy, low level of accuracy, medium, high level of accuracy, very high level of accuracy. This ranking of answers is identical to the answers rated in the author's questionnaire, i.e. with the answers ranked by relevance on the following scale: 1 - I absolutely disagree, 2 - I disagree, 3 - I am not sure, 4 - mostly true, 5 I completely agree. Research data have been collected through a questionnaire, processed and displayed by the Chi-Square and Friedman Tests, which identified average values and obvious differences in displayed values of sustainable tourism development indicators in selected protected areas.

\section{Results}

Respondents traveled at least once to certain protected areas that are the subject of the survey and they used certain services within those areas during the last 5 years. There is a claim that not all the tourists have visited all protected areas that are chosen for the survey, which will not affect average values in certain questions. The cities from which the respondents traveled to these destinations are Belgrade, Novi Sad, Kragujevac, Kraljevo, Pančevo, Zagreb, Budapest, Vienna, Zurich and Bucharest (all respondents are from the European continent). Each respondent explained which protected areas had been visited before the questionnaire. Each completed questionnaire is valid for analysis. This means that all 450 respondents validly completed the questionnaire. Each respondent was able to accurately determine the degree of influence of each indicator in the questionnaire based on their own experience. The structure of the respondents is shown in Table 1 . The obtained results are shown in the form of average values (mean), according to the percentage of accuracy and representation. The answers to the questions regarding the presence of certain negative indicators of sustainable tourism development were analyzed and presented in negative values, as potential threats for management and sustainable development of the destination (Table 2).

Improving Vojvodina's tourism offer can be achieved through area protection and sustainable tourism development. For the analysis of its current condition, the selected protected areas were taken as examples in order to determine the sustainability of relevant indicators of sustainable tourism development, and which can be used for successful management of the tourism destination (Fennell, Weaver, 2005; Ghanem, Elgamal, 2016; Maksin et al., 2018). The display of average positive and negative values and conditions, obtained after the analysis of the respondents' answers, are shown in Table 2, Figure 2. 
Table 1. Respondents' Profile

\begin{tabular}{|c|c|c|c|c|}
\hline & Gender & Frequency & \multicolumn{2}{|c|}{$\%$} \\
\hline \multicolumn{2}{|l|}{ Male } & 212 & \multicolumn{2}{|c|}{47.11} \\
\hline \multicolumn{2}{|c|}{ Female } & 238 & \multicolumn{2}{|c|}{52.89} \\
\hline \multicolumn{2}{|l|}{ Total } & 450 & \multicolumn{2}{|c|}{100.00} \\
\hline \multicolumn{2}{|r|}{ Education } & Frequency & \multicolumn{2}{|c|}{$\%$} \\
\hline \multicolumn{2}{|c|}{ Primary Education } & 30 & \multicolumn{2}{|c|}{6.67} \\
\hline \multicolumn{2}{|c|}{ Secondary Education } & 184 & \multicolumn{2}{|c|}{40.89} \\
\hline \multicolumn{2}{|c|}{ Higher Education } & 155 & \multicolumn{2}{|c|}{34.44} \\
\hline \multicolumn{2}{|c|}{ High Education } & 81 & \multicolumn{2}{|c|}{18.00} \\
\hline \multicolumn{2}{|l|}{ Total } & 450 & \multicolumn{2}{|c|}{100.00} \\
\hline \multirow{4}{*}{\multicolumn{2}{|c|}{ Age structure }} & $\mathrm{n}$ & Min & $\operatorname{Max}$ \\
\hline & & 450 & 18 & 75 \\
\hline & & Mean & \multicolumn{2}{|c|}{ Std. Dev. } \\
\hline & & 34.22 & \multicolumn{2}{|c|}{16.321} \\
\hline \multirow{2}{*}{\multicolumn{2}{|c|}{ Frequency of Visits }} & \multicolumn{2}{|c|}{ Responses } & \multirow{2}{*}{$\%$ of Cases } \\
\hline & & $n$ & $\%$ & \\
\hline FG & National Park „Fruška Gora" & 320 & 21.05 & 71.11 \\
\hline PA & Nature Park „Palić" & 298 & 19.61 & 66.22 \\
\hline ZA & Nature Reserve „Zasavica“ & 244 & 16.05 & 54.22 \\
\hline OB & Special Nature Reserve „Obedska Bara“ & 238 & 15.66 & 52.89 \\
\hline DP & Special Nature Reserve „Deliblatska Peščara" & 210 & 13.82 & 46.67 \\
\hline KPR & Special Nature Reserve „Koviljsko-Petrovaradinski Rit" & 151 & 9.93 & 33.56 \\
\hline MGB & Special Nature Reserve „Meadows of Great Bustard“ & 59 & 3.88 & 13.11 \\
\hline & Total & 1,520 & 100 & 337.78 \\
\hline
\end{tabular}

Table 2. Analysis of the Average Values of Sustainable Tourism Development Indicators

\begin{tabular}{|c|l|c|c|c|c|c|c|c|c|}
\hline \multirow{2}{*}{$\mathbf{N}$} & \multirow{2}{*}{ Indicators } & DP & FG & KPR & OB & ZA & PA & MGB \\
\cline { 2 - 9 } & & \multicolumn{5}{|c|}{ Mean } \\
\hline 1 & Favorable location & 4.02 & 4.21 & 2.22 & 3.89 & 2.64 & 4.33 & 1.98 \\
\hline 2 & Built traffic infrastructure & 4.33 & 4.55 & 2.17 & 4.44 & 3.69 & 4.39 & 3.68 \\
\hline 3 & National protection status & 3.96 & 3.21 & 3.98 & 4.69 & 4.14 & 4.17 & 4.58 \\
\hline 4 & International protection status & 4.10 & 2.69 & 4.11 & 4.14 & 4.13 & 3.96 & 2.86 \\
\hline 5 & Sufficient number of supporting facilities & 2.98 & 3.11 & 1.98 & 3.86 & 3.01 & 4.17 & 1.33 \\
\hline 6 & Accommodation service premises & 3.67 & 3.15 & 1.96 & 2.11 & 1.11 & 3.22 & 1.23 \\
\hline 7 & The significance of protection for species sustainability & 4.12 & 3.45 & 4.69 & 4.51 & 5.00 & 4.01 & 4.67 \\
\hline 8 & The role of the local community & 4.22 & 3.15 & 3.98 & 4.11 & 4.66 & 3.89 & 4.49 \\
\hline 9 & Developed ecotourism & 3.19 & 4.11 & 3.11 & 3.07 & 3.11 & 2.96 & 2.35 \\
\hline 10 & Potential positive social-cultural effects of tourism & 4.55 & 3.22 & 4.44 & 3.86 & 4.14 & 4.66 & 1.24 \\
\hline 11 & Events & 1.98 & 2.98 & 2.11 & 1.69 & 1.33 & 3.98 & 1.12 \\
\hline
\end{tabular}




\begin{tabular}{|c|c|c|c|c|c|c|c|c|}
\hline \multirow{2}{*}{$\mathrm{N}$} & \multirow{2}{*}{ Indicators } & DP & FG & KPR & OB & ZA & PA & MGB \\
\hline & & \multicolumn{7}{|c|}{ Mean } \\
\hline 12 & Potential positive economic effects of tourism & 4.59 & 4.66 & 4.62 & 4.74 & 4.15 & 4.19 & 3.56 \\
\hline 13 & Potential positive ecological effects of tourism & 4.71 & 4.55 & 4.66 & 5.00 & 5.00 & 4.33 & 3.21 \\
\hline 14 & Available visitor center & 4.00 & 3.98 & 1.96 & 4.00 & 4.72 & 4.12 & 3.00 \\
\hline 15 & Marked walking and educational trails & 4.39 & 4.12 & 1.98 & 3.69 & 2.98 & 3.14 & 3.86 \\
\hline 16 & Eco-trails & 4.12 & 3.89 & 1.33 & 1.76 & 2.36 & 2.96 & 2.69 \\
\hline 17 & The application of the carrying capacity of the area & 3.19 & 2.11 & 1.17 & 2.03 & 3.14 & 2.89 & 3.22 \\
\hline 18 & Endemic species & 4.77 & 1.98 & 3.96 & 4.11 & 4.66 & 3.11 & 4.12 \\
\hline 19 & The availability of excursion tourism & 4.89 & 4.56 & 4.11 & 4.66 & 4.12 & 5.00 & 3.11 \\
\hline 20 & The availability of scientific tourism & 4.91 & 4.69 & 4.44 & 4.77 & 4.87 & 4.77 & 4.41 \\
\hline 21 & Photographing rare birds and animals & 4.33 & 4.29 & 4.13 & 3.11 & 2.47 & 4.03 & 4.66 \\
\hline 22 & Bird and animal watching & 4.56 & 4.39 & 4.69 & 4.02 & 4.66 & 3.96 & 4.89 \\
\hline 23 & $\begin{array}{l}\text { Eliminated the problem of wastewater from the } \\
\text { settlements }\end{array}$ & 4.21 & 3.11 & 2.69 & 3.66 & 3.16 & 2.89 & 4.42 \\
\hline 24 & Visible ecological benefits & 3.11 & 2.98 & 3.77 & 4.11 & 4.12 & 3.69 & 5.00 \\
\hline 25 & Hydrographic potentials & 3.17 & 4.56 & 5.00 & 5.00 & 5.00 & 5.00 & 4.40 \\
\hline 26 & The availability of ethno-villages or settlements & 2.56 & 2.11 & 4.11 & 3.17 & 4.16 & 3.74 & 3.13 \\
\hline 27 & Favorable climate & 4.11 & 4.55 & 4.39 & 4.03 & 3.96 & 4.19 & 4.12 \\
\hline 28 & The proximity to potential environmental pollutant & 4.14 & 2.21 & 4.44 & 4.66 & 4.86 & 4.22 & 3.14 \\
\hline 29 & The use of natural resources & 4.32 & 3.96 & 4.32 & 4.21 & 4.11 & 4.39 & 2.11 \\
\hline 30 & The presence of domestic animals & 2.74 & 4.14 & 4.69 & 2.98 & 4.66 & 1.19 & 1.03 \\
\hline 31 & Potential negative social-cultural effects & 1.11 & 1.96 & 1.22 & 1.39 & 2.11 & 1.39 & 1.11 \\
\hline 32 & Endangered species according to IUCN & 4.09 & 3.78 & 4.59 & 4.66 & 4.47 & 4.11 & 5.00 \\
\hline 33 & The proximity to agricultural land & 5.00 & 4.65 & 5.00 & 4.39 & 4.66 & 3.74 & 5.00 \\
\hline
\end{tabular}

Legend: DP - Special Nature Reserve "Deliblatska Peščara; FG - National Park "Fruška Gora"; KPR - Special Nature Reserve "Koviljsko-Petrovaradinski Rit"; OB - Special Nature Reserve "Obedska Bara"; ZA - Special Nature Reserve "Zasavica"; PA Nature Park "Palić"; MGB -Special Nature Reserve "Meadows of Great Bustard".

Source: Author calculation

In Table 2, there is a significant frequency in stated values. Its determination is significant for the individual analysis of average indicators; in this case, the indicators that define the level of consistency of sustainable tourism development in selected protected natural areas (Figure 2). Frequencies can be displayed in Table 3, using the Chi-Square Test. 


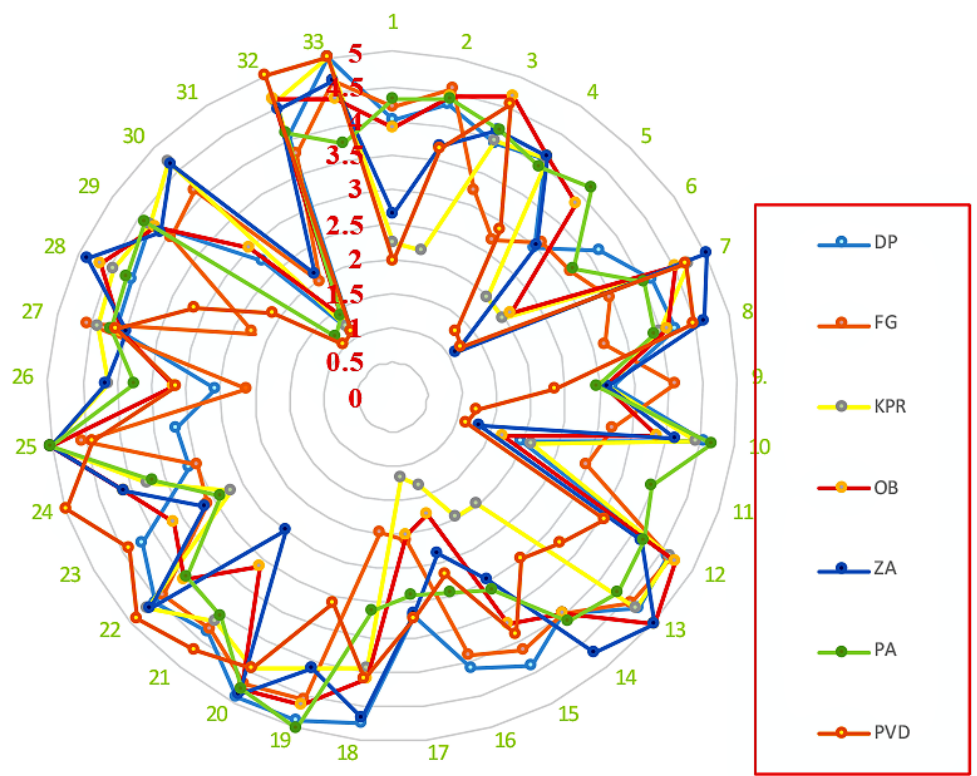

Figure 2. Zones of Average Development Indicators Values by Areas (N1, N2 ... N33) Source: Author calculation

Table 3. Frequencies of Development Indicators

\begin{tabular}{|c|c|c|c|c|c|c|c|}
\hline & DP & FG & KPR & OB & ZA & PA & MGB \\
\hline Chi-Square & $16.636^{a}$ & $14.909^{b}$ & $10.182^{c}$ & $13.364^{a}$ & $22.121^{b}$ & $12.091^{d}$ & 7.667 \\
\hline$d f$ & 17 & 16 & 14 & 17 & 16 & 15 & 21 \\
\hline Asymp. Sig. & .479 & .531 & .749 & .712 & .139 & .672 & .996 \\
\hline$\chi^{2}$ & 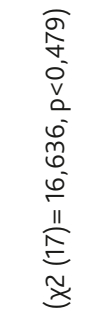 & 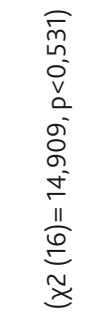 & 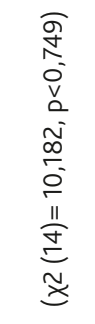 & 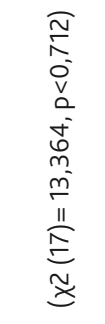 & 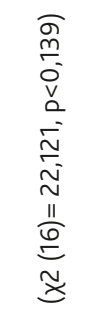 & 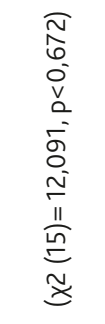 & 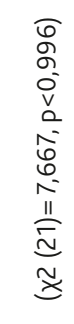 \\
\hline
\end{tabular}

${ }^{a} 18$ cells (100.0\%) have expected frequencies less than 5 . The min expected cell frequency is 1.8; ${ }^{b} 17$ cells (100.0\%) have expected frequencies less than 5 . The min expected cell frequency is 1.9; '15 cells (100.0\%) have expected frequencies less than 5 . The min expected cell frequency is 2.2; ${ }^{d} 16$ cells (100.0\%) have expected frequencies less than 5 . The min expected cell frequency is 2.1; e22 cells (100.0\%) have expected frequencies less than 5 . The min expected cell frequency is 1.5. source: author calculation 


\section{Discussion}

After analyzing the assessment of indicator values and grouping them according to the sectors within selected protected areas, it is significant to examine possible differences in the assessment of the significance of certain claims within given answers. Determining the differences will influence the definition of conclusions regarding the effects of relevant indicators on tourism destination management. This can be done by the Friedman Test which can enable us to monitor the ranking of responses and the consistency of certain differences, that can be significant for reaching conclusions regarding as to what extent certain indicators influence the destination management, and how we can influence the increase in the quality of the destination by decreasing them (Tables 4,5 ).

Table 4. Analysis of Consistent Differences in Given Responses

\begin{tabular}{|c|c|c|c|c|c|c|}
\hline Protected area & N & Mean & Std. deviation & Min & Max & Mean rank \\
\hline DP & 33 & 3.885 & .8811 & 1.1 & 5.0 & 4.55 \\
\hline ZA & 33 & 3.806 & 1.0773 & 1.1 & 5.0 & 4.42 \\
\hline FG & 33 & 3.618 & .8907 & 2.0 & 4.7 & 3.65 \\
\hline KPR & 33 & 3.518 & 1.2423 & 1.2 & 5.0 & 3.68 \\
\hline OB & 33 & 3.779 & 1.0015 & 1.4 & 5.0 & 4.26 \\
\hline PA & 33 & 3.785 & .8639 & 1.2 & 5.0 & 4.09 \\
\hline MGB & 33 & 3.294 & 1.3262 & 1.0 & 5.0 & 3.35 \\
\hline
\end{tabular}

Source: Author calculation

Table 5. Total Differencesa

\begin{tabular}{|c|c|}
\hline Analysis & Evaluation \\
\hline $\mathrm{N}$ & 33 \\
\hline Chi-Square & 8.765 \\
\hline $\mathrm{df}$ & 6 \\
\hline Asymp. Sig. & .187 \\
\hline \multicolumn{2}{|c|}{ a. Friedman Test } \\
\hline
\end{tabular}

Source: Author calculation

Based on the results of the Friedman Test (Tables 4, 5), it can be concluded that there is a statistically significant difference in the assessments of indicator representation of sustainable tourism development in each of the observed protected areas, estimated by tourists: $\left(\mathrm{X}^{2}(6)=\right.$ $8,765, \mathrm{p}<0,187)$.

The relevant indicators for managing the tourism destination Special Nature Reserve "Deliblatska Peščara" are at the same time graded with the highest average values. The most significant indicators are the possibility of development of scientific tourism, excursion tourism, the presence of endemic plant and animal species, and others. As the lowest graded indicators from the aspect of sustainable management of this destination are the following: the absence of events such as social-cultural tourism motive, lack of ethno-villages, insufficient construction of supporting tourism facilities, and other low-graded indicators. The most significant threats are the proximity of agricultural land, the use of natural resources the proximity of potential environmental pollutants, and endangered IUCN animal species, (Table 2). Analyz- 
ing the responses did not determine the presence of negative social-cultural effects of tourism, i.e. the development of tourism is widely accepted in this protected area by the local community. Sustainable development goals: the implementation of a proper management plan and protection monitoring of this protected area can influence the reduction of differences in relevant indicator values of sustainable tourism development (Ceausu et al., 2015; Romão, 2018), which can increase the total value of this protected area as a tourism destination (Selva, 2011).

National Park "Fruška Gora" has the highest graded average values in terms of the following relevant indicators: the possible development of scientific tourism, the possibility of achieving positive economic benefits from tourism, the possibility of excursion tourism development, built traffic infrastructure, possible positive ecological effects of tourism and favorable climate, observing birds and animals, favorable geographical and tourism position, and other values. As the lowest graded indicators of sustainable tourism development are: endemic plant and animal species, the application of the carrying capacity of the area and the availability of ethno-villages and settlements, eliminated the problem of wastewater, and other low graded indicators. As the most significant threats are: the proximity of agricultural land, the presence of domestic animals, the use of natural resources, and endangered IUCN animal species. Sustainable development goals: with a proper plan of area management, the strivings should be directed to the reduction of differences in average values of these indicators. Sustainable tourism development, ecotourism, and area protection should exist in the most significant potentials of this protected area as significant tourism destinations (Eagles, 2014; Janssen, 2009; Geneletti et al., 2018), and those are as follows: the existence of national and international protection frameworks, the activity of the local community (Shafer, 2015), the availability of events, and the possibility of the promotion of social values, the zoning of the area (Price, 2006; Lehtomäki, Moilanen, 2013), relict plants was recorded (Savić et al., 2008) and other values presented in Table 2 .

In the management of a protected area as a tourism destination, Special Nature Reserve "Koviljsko - Petrovaradinski Rit", the following significant indicators that the respondents graded with the highest average values should be considered: the existence of water as a valuable resource, i.e. wetlands, the significance of protection for species sustainability, the possibility for the development of tourism based on observing birds and animals, endemic species and the possibility of the achievement positive ecological benefits from tourism development. The planning of the use of these values should be managed with caution because this is a very fragile destination due to its specific elements (Tisdell, Wilson, 2005). The negative high-graded indicators that are threatening to this destination are the proximity of agricultural land and the constant activities of domestic animals. The respondents stated that there are no negative social-cultural effects of tourism in this destination, i.e. the visitors were accepted by the local community. Sustainable management of this destination should improve the values such as strengthening and expanding visitor centers and observation posts, as well as basic facilities for accommodation services (Table 2). This would reduce potential differences in the average values of sustainable tourism development indicators. The presence of a great number of high-graded average values indicates that the Special Nature Reserve "Koviljsko - Petrovaradinski Rit" is an exceptional area for creating a high-quality ecological and sustainable tourism destination. Environmental indicators are crucial for the understanding and the promotion of psychological positivity.

Among significant indicators of sustainable tourism development in Special Nature Reserve "Obedska Bara" the highest graded are following indicators: hydrographic potential as a basic resource and potential ecological effects of tourism, the possibility of the scientific tourism 
development, the adequate status of area protection, and other low-ranked average values that are presented in Table 2 . The proximity to a potential environmental pollutant (the indicators near Šabac city), endangered species according to IUCN, and the proximity to agricultural land should be distinguished as the most significant threats in this destination. The implementation of a proper plan for the management of this protected area, along with protection monitoring, can reduce the differences in the values of the relevant indicators of sustainable tourism development (Kar, 2013).

By analyzing the data in Table 2, it is concluded that there are more significant differences in average values of the indicators of sustainable tourism development in Special Nature Reserve "Zasavica". Here, the respondents emphasized the significance of the protection for species sustainability as the highest values, potential positive ecological and tourism benefits, as well as hydrographical potential as the basic resources. Sustainable development goals: the reduction of current differences in stated values of the mentioned indicators should be achieved through the increase in lower values, such as accommodation facilities, the availability of events, and eco-trails, as well as through the elimination of potential threats for sustainable management of this protected area, as follows: the proximity to a potential pollutant, the presence of domestic animals, and the proximity to agricultural land, (Table 2).

By analyzing the graded values of the indicators of sustainable tourism development in Nature Park "Palić", (Table 2), some significant differences in presented average values can be seen. Among high graded values are as follows: the possibility for the development of excursion tourism and the present hydrographical potential, potential social-cultural benefits from tourism, and other values. As the most significant threats, the respondents emphasized the use of natural resources, the proximity to potential pollutants, and endangered species according to the IUCN category. Sustainable development goals: by implementing the proper management plan for this protected area, and by protection monitoring, it may be possible to reduce the differences in the values of the relevant indicators of sustainable tourism development. The goal is to favor the conservation of natural resources in this protected area, which contributes to a growing global awareness of the need to protect biodiversity.

By analyzing the data in Table 2, the consistency of the differences in graded values of the sustainable development indicators in Special Nature Reserve "Meadows of Great Bustard", but also the lowest total average value. Among the most significant potentials, the respondents emphasized notable ecological protection benefits, observing birds and animals, the significance of the protection for species sustainability, the possibility of enjoying and photographing nature, and other lower values. Among the most significant threats to the management and protection of this area, the respondents emphasized the following: endangered species according to the IUCN and the proximity of agricultural land. A relatively lower overall average value, gathered by the respondents' grading of the indicators of sustainable development, can be related to the fact that this nature reserve represents still insufficiently exploited tourism destination, visited by only 59 respondents (Table 1). Sustainable development goals: total protected species. The most effective and sustainable way of managing natural systems involves 'working with nature' (Gordon et al., 2018). Ecotourism is a possible approach to addressing both biodiversity conservation (Castro et al., 2015). 


\section{Conclusion}

The seven selected protected areas in the AP of Vojvodina represent a significant sample for the analysis of tourism offer at the level of the region. Within these areas, 450 respondents ranked their answers in 33 questions regarding the presence and effects of sustainable tourism development indicators. At the same time, the questions were identified with these indicators. By analyzing the answers, significant differences were found in the average values among the graded indicators (Tables 2, 3, and 4). Protected areas with the highest average values are the Special Nature Reserve "Deliblatska Peščara", the Special Nature Reserve "Zasavica", and Nature Park "Palić" (Table 4). In these protected areas, even the smallest differences are present in the respondents' answers. By minimizing, or eliminating the negative indicators as the threats for a protected natural site (the questions $\mathrm{N}_{2} 8$... N33), (Table 2), it is possible to increase the total value of these tourism destinations, and, therefore, the value of the area at the level of the overall tourism offer. As the most significant threats for each destination, the respondents noted the endangered species according to the IUCN category, the proximity of the agricultural land with chemically treated crops, the proximity of significant pollutants, and the presence of domestic animals.

The analysis of the research results concludes that significant natural factors are present within the selected protected natural areas. Respondents pointed out the importance of geographical location, favorable climate, rich flora and fauna, wetlands and other factors for tourism. The results can benefit to tourism planning. Forms of tourism that can be developed within these tourism destinations are natural forms of tourism, ecotourism, bird and animal watching, sports tourism, scientific tourism, excursions, wine tourism, events, nautical tourism and other forms based on nature. For social factors, the greater involvement of the local community in the systems managed by protected natural areas and planning the development of tourism within these destinations is significantly greater. It is necessary to reduce the negative human impacts on the environment of these destinations. The results of the research also indicated the exploitation of natural resources within the reserve. This must be prevented by certain measures and management activities. Implementation of the management plans of these protected areas, proper monitoring and the improvement of protection can minimize negative tourism impacts or even eliminate them. It is tourism that can be a catalyst for these activities. In addition to the elimination of the negative effects of the area users, overall ecological, economic and social-cultural benefits for the destination can be achieved through tourism.

By directly increasing the values of sustainable tourism development indicators, reducing the differences in current values, and reducing or eliminating the indicators that pose a threat to protected areas, the significance of the tourism destination, as an overall spatial unit (Hall, 2010), increases, which confirms the basic hypothesis in this paper. The extent, to which the entities in the protection systems are involved in all of this and how great the financial values are needed to be for establishing such models of management will be discovered by some future research. 


\section{References}

Ballantyne, R., Packer, J. 2013. Ecotourism: Themes and Issues. In: Ballantyne, R., Packer, J. (Eds.) International Handbook on Ecotourism. Edward Elgar, Cheltenham, 1-6.

Bennett, N.J., Whitty, T.S., Finkbeiner, E., Pittman, J., Bassett, H., Gelcich, S., Allison, E.H. 2018. Environmental Stewardship: A Conceptual Review and Analytical Framework. Environmental Management 61(4), 597-614. https://doi.org/10.1007/s00267-017-0993-2

Brandt, J., Christensen, A.A., Svenningsen, S.R., Holmes, E. 2013. Landscape Practise and Key Concepts for Landscape Sustainability. Landscape Ecology 28(6), 1125-1137. https://doi. org/10.1007/s10980-012-9777-5

Buclet, N., Lazarević, D. 2015. Principles for Sustainability: the Need to Shift to a Sustainable Conventional Regime. Environment, Development and Sustainability 17(1), 83-100. https:// doi.org/10.1007/s10668-014-9539-4

Carr, A., Ruhanen, L., Whitford, M. 2016. Indigenous Peoples and Tourism: the Challenges and Opportunities for Sustainable Tourism. Journal of Sustainable Tourism 24(8-9), 1067-1079.

Castro, A.J., Martín-Lopez, B., López, E., Plieninger, T., Alcaraz-Segura, D., Vaughn, C.C., Cabello, J. 2015. Do Protected Areas Networks Ensure the Supply of Ecosystem Services? Spatial Patterns of Two Nature Reserve Systems in Semi-Arid Spain. Applied Geography 6o, 1-9. https://doi.org/10.1016/j.apgeog.2015.02.012

Ceausu, S., Gomes, I., Pereira, H.M. 2015. Conservation Planning for Biodiversity and Wilderness: A Real-World Example. Environmental Management 55(5), 1168-118o. https://doi. org/10.1007/soo267-015-0453-9

Cvijanović, D., Stanišić, T., Leković, M., Kostić, M. 2020. Indicators of Agricultural and Rural Development in the East Central and South-East European Countries. Agriculture \& Forestry 66(2), 19-32. https://doi.org/10.17707/AgricultForest.66.2.02

Eagles P.F.J. 2014. Research Priorities in Park Tourism. Journal of Sustainable Tourism 22(4), 528-549. https://doi.org/10.1080/09669582.2013.785554

Environmental protection programme of AP Vojvodina, for period 2016-2025 - "Official Gazette of AP Vojvodina", 10/2016. Serbia (in Serbian).

Fennell, D., Weaver, D. 2005. The Ecotourium Concept and Tourism-Conservation Symbiosis. Journal of Sustainable Tourism 13(4), 373-39o. https://doi.org/10.1080/09669580508668563

Fennell, D.A. 2015a. Ecotourism. Routledge, Taylor \& Francis Group, London \& New York.

Fennell, D.A. 2015b. Tourism and the Precautionary Principle in Theory and Practice. In: Hall, C.M., Gössling, S., Scott, D. (Eds.) The Routledge Handbook of Tourism and Sustainability. Routledge, Taylor \& Francis Group, London \& New York, 67-77.

Gambino, R. 2015. Introduction: Reasoning on Parks and Landscapes. In: Gambino, R., Peano, A. (Eds.) Nature Policies and Landscape, Policies Towards an Alliance. Springer, New York, 1-24. https://doi.org/10.1007/978-3-319-05410-0

Geneletti, D., Scolozzi, R., Esmail, B.A. 2018. Assessing Ecosystem Services and Biodiversity Tradeoffs Across Agricultural Landscapes in a Mountain Region. International Journal of Biodiversity Science, Ecosystem Services \& Management 14(1), 188-208. https://doi.org/10.1 080/21513732.2018.1526214

Ghanem, M., Elgammal, I. 2016. Communicating Sustainability Through a Destination's Website: A Checklist to Inform, Motivate, and Engage Stakeholders. Journal of Travel E Tourism Marketing 34(6), 793-805. https://dx.doi.org/10.1080/105484.08.2016.1233928 
Gordon, J.E., Crofts, R., Díaz-Martínez, E., Woo, K.S. 2018. Enhancing the Role of Geoconservation in Protected Area Management and Nature Conservation. Geoheritage 10(2), 191203. https://doi.org/10.1007/s12371-017-024.0-5

Hall, C.M. 2010. Tourism and Biodiversity: More Significant Than Climate Change? Journal of Heritage Tourism 5(4), 253-266. https://doi.org/10.1080/1743873X.2010.517843

Hoang, T.T.H., Rompaey, A.V., Meyfroidt, P., Govers, G., Vu, K. C., Nguyen, A. T., Hens L., Vanacker, V. 2020. Impact of Tourism Development on the Local Livelihoods and Land Cover Change in the Northern Vietnamese Highlands. Environment, Development and Sustainability 22, 1371-1395. doi:10.1007/s10668-018-0253-5

Hodder, K.H., Newton, A.C., Cantarello, E., Perrella, L. 2014. Does Landscape-Scale Conservation Management Enhance the Provision of Ecosystem Services? International Journal of Biodiversity Science, Ecosystem Services \& Management 10(1), 71-83. https://doi.org/10.1 o80/21513732.2014.883430

Holden, A. 2016. Environment and Tourism. Routledge, Taylor \& Francis Group, London \& New York.

Janssen, J. 2009. Sustainable Development and Protected Landscapes: the Case of The Netherlands. International Journal of Sustainable Development \& World Ecology 16(1), 37-47. https://doi.org/10.1080/13504500902757981

Joshi, A., Kale, S., Chandel, S., Pal, D.K. 2015. Likert Scale: Explored and Explained. British Journal of Applied Science \& Technology 7(4), 396-403. https://doi.org/10.9734/ BJAST/2015/14975

Kar, D. 2013. Wetlands and Lakes of the World. Springer, New York. https://dx.doi. org/10.1007/978-81-322-1023-8

Kostić, M., Ratković, M., Forlani, F. 2019. Eco-Hotels as an Example of Environmental Responsibility and Innovation in Savings in the Hotel Industry. Hotel and Tourism Management 7(2), 47-56. https://doi.org/10.5937/menhottur1902047K

Kristić, V., Đurađević, M., Trišić, I. 2020. The Impact of Complemetary Medicine on Sustainable Tourism Development Through Event and Nature-Based Tourism. Economics of Agriculture 67(2), 377-390. https://doi.org/10.5937/ekoPolj2002377K.

Kruger, M., Viljoen, A., Saayman, M. 2017. Who Visits the Kruger National Park and Why? Identifying Target Markets. Journal of Travel \& Tourism Marketing 34(3), 312-340. https:// doi.org/10.1080/10548408.2016.1156618

Lazić, L., Pavić, D., Stojanović, V., Tomić, P., Romelić, J., Pivac, T., et al. 2008. Zaštićena prirodna dobra i ekoturizam Vojvodine [Protected Areas and Ecotourism of Vojvodina]. Departman za Geografiju, Turizam i Hotelijerstvo, Prirodno-matematički fakultet, Novi Sad.

Lehtomäki, J., Moilanen, A. 2013. Methods and Workflow for Spatial Conservation Prioritization Using Zonation. Environmental Modelling \& Software 47, 128-137. http://dx.doi. org/10.1016/j.envsoft.2013.05.001

Leković, M. 2020. Cognitive Biases as an Integral Part of Behavioral Finance. Economic Themes 58(1), 75-96. https://doi.org/10.2478/ethemes-2020-0005

Liburd, J.J., Becken, S. 2017. Values in Nature Conservation, Tourism and UNESCO World Heritage Site Stewardship. Journal of Sustainable Tourism 25(12), 1719-1735. https://doi.org 110.1080/09669582.2017.1293067

Maksin, M., Pucar, M., Milijić, S., Korać, M. 2011. Održivi razvoj turizma u Evropskoj Uniji i Srbiji [Sustainable development of tourism in the EU and Serbia]. Institut za arhitekturu i urbanizam Srbije, Beograd. 
Maksin, M., Ristić, V., Nenković-Riznić, M., Mićić, S. 2018. The Role of Zoning in the Strategic Planning of Protected Areas: Lessons Learnt From EU Countries and Serbia. European Planning Studies 26(4), 838-872. https://doi.org/10.1080/09654313.2018.1426736

McCool, S.F. 2016. The Changing Meanings of Sustainable Tourism. In: McCool, S.F., KeithBosak, K. (Eds.) Reframing sustainable tourism. Springer, New York, 13-32. https://doi. org/10.1007/978-94-017-7209-9

Minin, E.D., Soutullo, A., Bartesaghi, L., Rios, M., Szephegyi, M.N., Moilanen, A. 2017. Integrating Biodiversity, Ecosystem Services and Socio-Economic Data to Identify Priority Areas and Landowners for Conservation Actions at the National Scale. Biological Conservation 206, 56-64. http://dx.doi.org/10.1016/j.biocon.2016.11.037

Muñoz, L., Hausner, V., Brown, G., Runge, C., Fauchald, P. 2019. Identifying Spatial Overlap in the Values of Locals, Domestic and International Tourists to Protected Areas. Tourism Management 71, 259-271.

Oprea, L., Ienciu, I., Tudorascu, M., Filip, L. 2015. Implications of Topography and Cadastre in Tourism Planning and Sustainable Development of "Alba Carolina" Vauban Citadel. Journal of Environmental Protection and Ecology 16(3), 1016-1023.

Pfueller, S.L., Lee, D., Laing, J. 2011. Tourism Partnerships in Protected Areas: Exploring Contributions to Sustainability. Environmental Management 48, 734-749. https://doi. org/10.1007/s00267-011-9728-y

Pivac, T., Blešić, I., Besermenji, S., Gavrilović, D. 2020. Attitudes of Local Population on the Importance of Events Nourishing Culture and Tradition of Croats in Vojvodina. Turizam 24(1), 46-46. https://doi.org/10.5937/turizam24-25376

Price, M.F. 2006. Global Recognition of Special Landscapes: Reconciling Sustainable Development and Conservation. International Journal of Biodiversity Science and Management 2(3), 142-145. https://doi.org/10.1080/17451590609618110

Romão, J. 2018. Tourism, Territory and Sustainable Development, Theoretical Foundations and Empirical Applications in Japan and Europe. Springer, New York. https://doi. org/10.1007/978-981-13-0426-2

Savić, D., Anačkov, G., Boža, P. 2008. New Chorological Data for Flora of the Pannonian Region of Serbia. Central European Journal of Biology 3(4), 461-470. https://doi.org/10.2478/s11535$\underline{008-0036-3}$

Selva, N., Kreft, S., Kati, V., Schluck, M., Jonsson, B.G., Mihok, B., et al. 2011. Roadless and Low-Traffic Areas as Conservation Targets in Europe. Environmental Management 48, 865-877. https://doi.org/10.1007/so0267-011-9751-Z

Shafer, C.L. 2015. Cautionary Thoughts on IUCN Protected Area Management Categories V-VI. Global Ecology and Conservation 3, 331-348. http://dx.doi.org/10.1016/j.gecco.2014.12.007

Stojanović, V. 2005. Degradation and Protection of Wetlands in Special Nature Reserves in Vojvodina. Geographica Pannonica 9, 24-28.

Stojanović, V., Lazić, L., Đunić, J. 2018. Nature Protection and Sustainable Tourism Interaction in Selected Ramsar Sites in Vojvodina (Northern Serbia). Geographica Pannonica 22(3), 201-207. doi:10.5937/g 22-16637

Stojanović, V., Savić, S. 2013. Management Challenges in Special Nature Reserve "Gornje Podunavlje" and Preparations for its Proclamation of Biosphere Reserve. Geographica Pannonica 17(4), 98-105.

Tisdell, C., Wilson, C. 2005. Perceived Impacts of Ecotourism on Environmental Learning and Conservation: Turtle Watching as a Case Study. Environment, Development and Sustainability 7(3), 291-302. https://doi.org/10.1007/s10668-004-7619-6 
Trišić, I. 2019. Opportunities for Sustainable Tourism Development and Nature Conservation in Special Nature Reserve "Deliblatska Peščara". Hotel and Tourism Management 7(1), 83-93. https://doi.org/10.5937/menhottur1901083T

Trišić, I., Štetić, S., Maksin, M. 2020a. The Significance of Protected Natural Areas for the Tourism of the Vojvodina Province (Northern Serbia) - Relevant Factors Analysis of the Sustainable Tourism Development. Spatium 43, 1-7. https://doi.org/10.2298/SPAT2043001T

Trišić, I., Štetić, S., Privitera, D., Nedelcu, A. 202ob. Wine Routes in Vojvodina Province, Northern Serbia - A Tool for Sustainable Tourism Development. Sustainability 12(1), 82. https:// doi.org/10.339o/su12010082

Valdivieso, J.C., Eagles, P.F.J., Gil, J.C. 2015. Efficient Management Capacity Evaluation of Tourism in Protected Areas. Journal of Environmental Planning E Management 58(9), 15441561. https://doi.org/10.1080/09640568.2014.937479

Ward, C., Stringer, L.C., Holmes, G. 2018. Protected Area Co-Management and Perceived Livelihood Impacts. Journal of Environmental Management 228, 1-12. https://doi.org/10.1016/j. jenvman.2018.09.018

Webb, J.A., Watts, R.J., Allan, C., Conallin, J.C. 2018. Adaptive Management of Environmental Flows. Environmental Management 61(3), 339-346. https://doi.org/10.1007/so0267-017$\underline{0981-6}$

West, J.M., Julius, S.H., Kareiva, P., Enquist, C., Lawler, J.J., Petersen, B., et al. 2009. U. S. Natural Resources and Climate Change: Concepts and Approaches for Management Adaptation. Environmental Management 44, 1001-1021. https://doi.org/10.1007/s00267-0099345-1

Whitelaw, P.A., King-Brian E.M., Tolkach, D. 2014. Protected Areas, Conservation and Tourism - Financing the Sustainable Dream. Journal of Sustainable Tourism 22(4), 584-6o3. https://doi.org/10.1080/09669582.2013.873445 